\title{
Biosorption combined with lipid production and growth inhibition of copper on the microalgal Pediastrum sp.
}

\author{
Khả năng hấp thu kết hợp với tích lũy sản phẩm lipid và ức chế sinh trưởng của đồng trên vi \\ tảo lục Pediastrum sp.
}

PHAM, Thanh Luu

Institute of Tropical Biology, Vietnam Academy of Science and Technology (VAST), 85 Tran Quoc Toan St., District 3, Ho Chi Minh City, Vietnam; Graduate University of Science and Technology, Vietnam Academy of Science and Technology (VAST), 18 Hoang Quoc Viet Street, Cau Giay District, Hanoi, Vietnam

\begin{abstract}
The contamination of heavy metals in surface waters is an environmental concern due to their persistence and nondegradation that poses a risk to the ecosystem and human health. Microalgae have been known for their ability to remove metals from wastewater and to produce biodiesel. In this study, the copper (Cu) stress on the growth and lipid contents of the green microalgal Pediastrum sp. were evaluated along with the removal capacity. The green microalga was grown in a culture medium with the presence of copper at concentrations of $0,0.1,0.5,2,5$ and $15 \mathrm{mg} / \mathrm{L}$ for one week. Results indicated that the growing tolerance levels of Pediastrum sp. in the presence of copper up to $2 \mathrm{mg} / \mathrm{L}$ and $\mathrm{Cu}$ inhibited the algal growth with the $96 \mathrm{~h}-\mathrm{EC} 50$ value of $6.67 \mathrm{mg} / \mathrm{L}$. However, the Pediastrum sp. showed a promising metal removal efficiency. Cu removal was from 83 to $95 \%$ by Pediastrum sp. with an initial concentration of Cu less than $2 \mathrm{mg} / \mathrm{L}$. The presence of a low level of Cu increased the lipid yield up to 18\%, but a high concentration of Cu has resulted in low removal efficiencies and decreasing lipid accumulation. The present study suggested the potential of employing green microalgae for wastewater treatment and biodiesel.
\end{abstract}

Ô nhiễm kim loại nặng trong nước mặt đang là vấn nạn môi trường ở nhiều quốc gia bởi vì kim loại nặng tồn tại lâu, khó có khả năng phân hủy và gây ảnh hưởng đến sức khỏe con người và hệ sinh thái. Vi tảo từ lâu được biết đến vì có khả năng loại bỏ kim loại nặng trong nước thải đồng thời tích lũy lipid cho sản xuất nhiên liệu sinh học. Trong nghiên cứu này khảo sát các tác động của đồng (Cu) như ức chế tăng trưởng, ảnh hưởng lên hàm lượng lipid tích lũy, khả năng loại bỏ kim loại cũng như hàm lượng kim loại tích lũy trong nội bào lên vi tảo lục Pediastrum sp. Vi tảo lục được phơi nhiễm với Cu ở các nồng độ 0 , 0,1, 0,5, 2, 5 và 15 mg/L trong thời gian 1 tuần ở điều kiện phòng thí nghiệm. Kết quả cho thấy vi tảo luc Pediastrum sp. có khả năng chống chịu với Cu ở ngưỡng nồng độ nhỏ hơn 2 mg/L. Nồng độ gây ức chế sinh trưởng 50\% sau 96h (96h-EC50) là 6,67 mg/L. Pediastrum sp. cho thấy có khả năng loại bỏ hiệu quả Cu ở ngưỡng nồng độ thấp hơn 2 mg/L với khả năng loại bỏ Cu lên đến 95\%. Ở nồng độ Cu 0,1 và 0,5 mg/L cũng cho thấy gia tăng hàm lượng lipid 18\% so với lô đối chứng, tuy nhiên khả năng loại bỏ kim loại Cu và hàm lượng lipid tích lũy giảm đi đáng kể khi Cu đồng ở ngưỡng 5 mg/L và 15 mg/L. Nghiên cứu này cho thấy có thể sử dung vi tảo Pediastrum sp. để xử lý ô nhiếm Cu ở nồng độ thấp và thu hồi lipid cho sản xuất nhiên liệu sinh học.

Keywords: wastewater treatment; biodiesel; heavy metal; bioremediation

\section{Introduction}

Human activities including agriculture and industrialization have resulted in metal discharges into aquatic ecosystems. Copper $(\mathrm{Cu})$ is one of the most commonly used metal in the world. Subsequently, the level of $\mathrm{Cu}$ in aquatic environments has been increasing in recent decades. In a recent study, Hamed et al. (2017) [1] reported that the annual discharge of $\mathrm{Cu}$ into the ocean is $9 \times 10^{6} \mathrm{t}$ per year. Although, $\mathrm{Cu}$ is an essential micronutrient required by photosynthetic species; however, it may be very toxic when present at high concentrations [2,3]. Cu has caused in decrease growth rate and reduction of pigment contents in microalgae; exposure to $\mathrm{Cu}$ has resulted in increased reactive oxygen species (ROS) in many autotroph organisms $[1,4,5]$. On the other hand, bioaccumulation of heavy metal in aquatic ecosystems and food chains can cause human health risk via trophic transfer. Therefore, many techniques such as reverse osmosis, electrophoresis, ultra-ion exchange, chemical precipitation, phytoremediation have been developed to remove heavy metals from contaminated water. However, all these methods have shown disadvantages such as high cost and energy requirements, or incomplete metal removal [6]. 
Microalgae have been considered a promising tool for their ability to remove various heavy metals from wastewater [6, 7], and their great potential in producing biodiesel [8]. Therefore, the coupling deals of advanced wastewater treatment and biofuel production based on microalgae is a promising solution. Many green algae such as Scenedesmus spp., Chlorella spp. have been employed as for removing heavy metals from wastewater and to produce biodiesel [9]. A combination of wastewater treatment and biofuel production is an environmentally friendly approach for stable development in the next century.

Previous studies have indicated that both living and nonliving biomass of microgreen algae are effective removal heavy metals from wastewater [10-12]. Several algae species have been found to be very effective in adsorption heavy metals from aqueous solutions. The ability to remove copper from water by living and non-living biomass of the microgreen algae species has been reported [12, 13]. These authors suggested that biological treatment of heavy metal contaminated water based on Scenesmus abundans is possible and that is adequately at high algae concentrations. In addition, Ouyang et al. (2012) [13] reported that several green algae such as Chlorella spp. and Scenedesmus spp. were effective in removing zinc and copper from aqueous solutions, with the highest removal efficiency being near 100\% [10,12]. However, Scenesesmus sp. and Chlorella sp. are commonly used for the purpose. Other microgreen algae species including Pediastrum spp., Ankistrodesmus spp., Staurastrum spp. are commonly present in water ponds but little known about their ability to remove heavy metals from contaminated waters. There are many unexplored algae species with high ability to remove toxic metal in the natural environment. Therefore, in this study, the green algal Pediastrum sp. was isolated from the Tri An Reservoir, a drinking water supply reservoir near Ho Chi Minh city, and used to examine the effective removal of Cu ion and investigate lipids accumulation. The biosorption and bioaccumulation of $\mathrm{Cu}$ from aqueous solution were investigated.

\section{Materials and methods}

\subsection{Alga isolation and cultivation}

The microgreen algal species (Pediastrum sp.) (Figure 1) was collected from the Tri An reservoir, Dong Nai province, Vietnam. The species was isolated under a microscope and grown in 500 Erlenmeyer flasks containing COMBO medium. All cultures were grown under laboratory conditions at $28 \pm 1{ }^{\circ} \mathrm{C}$ under a $12 \mathrm{~h}: 12 \mathrm{~h}$ period light-dark cycle with a light intensity of $50 \mu \mathrm{mol}$ photons $/ \mathrm{m}^{2} / \mathrm{s}$. The autoclaved medium was renewed every month to maintain the culture under laboratory conditions.

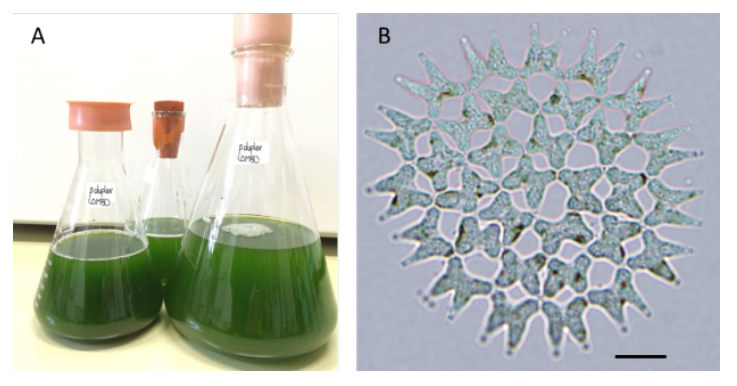

Figure 1. Stock culture (A), and morphology of Pediastrum sp. under a microscope (B). Scale bar: $20 \mu \mathrm{m}$.

\subsection{Biosorption and growth inhibition experiment}

The stock solution $1000 \mathrm{mg} / \mathrm{L}$ of copper $\mathrm{Cu}\left(\mathrm{NO}_{3}\right)_{2}$ (Titrisol, Merck, Germany) was used to prepared experimental solutions with concentration of $0,0.1,0.5,2,5$ and $15 \mathrm{mg} / \mathrm{L}$. The living cell of Pediastrum sp. was exposed to copper with design concentration in Erlenmeyer flasks (300 mL) containing $200 \mathrm{~mL}$ culture medium. The initial cell density of Pediastrum sp. was $5 \times 10^{4}$ cell $/ \mathrm{mL}$. About $5 \mathrm{~mL}$ of samples were taken every day for a period of 7 days. The density of cells was measured by using Rafter counting chamber under an Olympus light microscope at a magnification of 100X. After 7 days, algal biomass was collected on GF/C filters (Whatman, Kent, England), dried completely and stored at $-20^{\circ} \mathrm{C}$ until analysis. $5 \mathrm{~mL}$ of filtrate was used for $\mathrm{Cu}$ analysis. Erlenmeyer flasks with Pediastrum sp. but without Cu were used as controls. All treatment was prepared in triplicate.

The Cu concentration that resulted in 50\% inhibition of alga growth after 96h (EC50-96h) was determined as following equation:

$$
\mu_{i}-j=\frac{\ln C j-\ln C i}{t_{j}-t_{i}}
$$

where $\mu_{i}-j$ is the average specific growth rate from the time i to time $j, t_{i}$ is the initial time of the exposure period, $t_{j}$ is the final time of exposure, $C i$ is the concentration of cells at the time i and $C j$ is the concentration of cells at time j.

Percentage inhibition of growth was calculated as:

$$
\% I r=\frac{\mu_{C}-\mu_{T}}{\mu_{C}} \times 100
$$

where \% Ir is the percent inhibition in average specific growth rate; $\mu_{C}$ is the mean value for the average specific growth rate $(\mu)$ in the control group and $\mu_{T}$ is the average specific growth rate for the treatment replicate.

\subsection{Measurement of total lipid content}

For total lipid extraction and measurement, the method of Bligh and Dyer's method [14] was applied. Briefly, about 50 $\mathrm{mg}$ dry biomass (M1) was digested with $4 \mathrm{~mL} \mathrm{HCl} 1 \mathrm{M}$ at 
$80^{\circ} \mathrm{C}$ for $30 \mathrm{~min}$ in $50 \mathrm{~mL}$ centrifuge tube (M0), after centrifugation (4000 rpm, 15 min), the liquid supernatant was discarded. Lipid was then extracted with $3 \mathrm{~mL}$ methanol: chloroform (2:1 v/v). After $3 \mathrm{~h}$, the chloroform layer was pipetted to a new $15 \mathrm{~mL}$ tube (M2), dried completely and the tube was then re-weighed (M3). Total lipid content (LC) was evaluated as follow: LC (\%) = $(\mathrm{M} 3-\mathrm{M} 2) /(\mathrm{M} 1-\mathrm{M} 0)$.

\subsection{Heavy metal extraction and measurement}

The content of Cu in algal biomass was extracted with $5 \mathrm{~mL}$ concentrated nitric acid (70\%) for $12 \mathrm{~h}$ at $80^{\circ} \mathrm{C}$. The samples were then centrifuged at 4000 rpm for $10 \mathrm{~min}$ under room temperature. The supernatant contained metals were preserved at $-20^{\circ} \mathrm{C}$ until analysis. Cu content was measured by using an inductively coupled plasma optical emission spectrometer (ICP OES). (VISTA PRO, Varian, Mulgrave, Australia). Briefly, an ICP OES equipped with a solid state detector, a cyclonic spray chamber, and a concentric nebulizer was used for Cu detection. The ICP OES condition used as follows: RF power: $1.3 \mathrm{~kW}$; gas: argon; plasma flow: $15 \mathrm{~L} / \mathrm{min}$; auxiliary flow: $1.5 \mathrm{~L} / \mathrm{min}$; nebulizer flow: $0.75 \mathrm{~L} / \mathrm{min}$; instrument stabilization delay: $15 \mathrm{~s}$; pump rate: 15 rpm; sample uptake delay: 70 s; number of replicates: 3; read time: 5 s; read: peak height; rinse time: $30 \mathrm{~s}$. The data are presented in $\mathrm{mg} / \mathrm{g}$ DW or $\mathrm{mg} / \mathrm{L}$ as appropriate. All samples were run in triplicate.

The removal rate $\mathrm{Q}(\%)$ and the biosorption capacity $\mathrm{q}$ ( $\mathrm{mg} / \mathrm{g}$ ) was calculated using the following formula:

$$
\begin{gathered}
Q=\frac{\mathrm{C} 0-\mathrm{C}}{\mathrm{C} 0} \times 100 \% \\
\mathrm{q}=\frac{\mathrm{C} 0-\mathrm{C}}{\mathrm{M}} \times \mathrm{V}
\end{gathered}
$$

where, $C_{0}$ and $C$ are the initial and final concentrations of $\mathrm{Cu}(\mathrm{II})(\mathrm{mg} / \mathrm{L})$, respectively. The $\mathrm{V}$ and $\mathrm{M}$ are the volume of solution $(\mathrm{mL})$ and the mass of dry algal biomass ( $\mathrm{g}$ ), respectively.

\subsection{Statistical analysis}

One-way analysis of variance (ANOVA) was employed to find out the differences between exposure groups and control groups. When the ANOVAs were significant, pairwise comparison with the Tukey's honestly significant difference (HSD) Post-hoc test was applied to detect significant differences between the exposure concentrations and the control. Data were transformed by $\log (X+1)$ to normalize the distribution before analysis. Cu concentration was presented as the mean \pm SD. The $p$ values less than 0.05 were considered statistically significant.

\section{Results and discussions}

\subsection{Algal growth}

Growth curve and growth inhibition of microalga Pediastrum sp. exposure to different Cu concentrations were shown in Figure 2a, b. Pediastrum sp. grew well in COMBO medium and reached maximal density after 6 days (Figure 2a). All treatment reached the stationary growth phase after 5 or 6 days. Cells density in the control treatments increased from $5 \times 10^{4}$ to $4 \times 10^{6}$ cells $/ \mathrm{mL}$ after 6 days of culture. Results also indicated that different concentration of Cu resulted in different effects on algal growth. Cu at a low concentration from 0.1 to 0.5 did not cause a significant effect on algal growth, but at $2 \mathrm{mg} / \mathrm{L}$ or higher, Cu caused a significant decline in the cells concentration of Pediastrum sp.

The algal growth inhibition was increased and dose dependence of $\mathrm{Cu}$. The EC50 values of Cu for inhibition of $50 \%$ of algal growth after $96 \mathrm{~h}$ was $6.67 \mathrm{mg} / \mathrm{L}$. Cu at the concentration of $2 \mathrm{mg} / \mathrm{L}$ or higher caused significant effects and dose-dependent increases on the growth of Pediastrum sp. Cu at $15 \mathrm{mg} / \mathrm{L}$ inhibited completely the growth of Pediastrum sp. (Figure 2b).
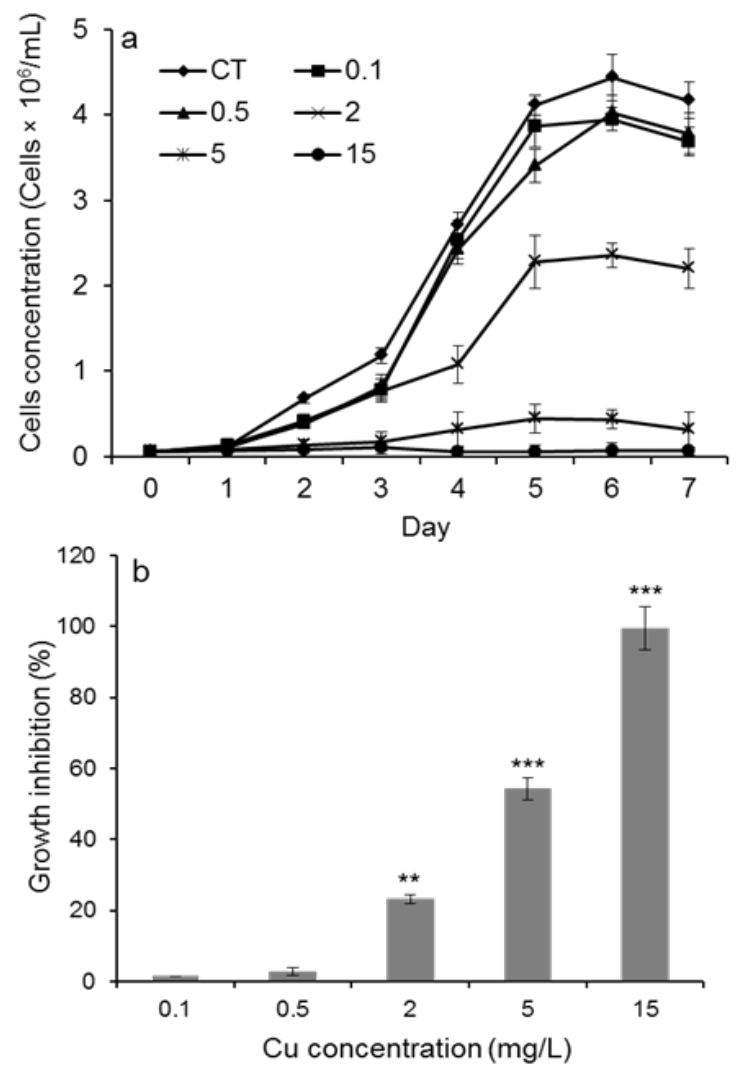

Figure 2. Growth curve (a) and growth inhibition (b) of Pediastrum sp. exposure to different $\mathrm{Cu}$ concentrations. Anova test $(* *, p<0.01 ; * * *, p<0.001)$.

Previous studies have reported that $\mathrm{Cu}$ is an essential nutrient to nearly all species from animal to algae $[15,16]$. However, high concentration of $\mathrm{Cu}$ in water environment 
may result in toxicity to aquatic organisms [17]. In addition, cu can generate various toxic effects on different aquatic species [18]. Levy et al. (2017) [19] reported that the effective concentrations of copper on the inhibition of the growth on the marine diatom Minutocellus polymorphous and the green algal Dunaliella tertiolecta at 96 h (96 h EC50) were $0.53,0.68 \mathrm{mg} / \mathrm{L}$, respectively. Some green microalgae such as Pediastrum, Pseudokirchneriella, and Chlorella could exhibit tolerance to heavy metals $[20,21]$. And the toxicity of heavy metals to green algae may depend on algal species. Schamphelaere et al. (2014) [22] reported that the microgreen alga Pseudokirchneriella subcapitata was 4-fold more sensitive to Cu than Chlorella kesslerii.

Heavy metals such as $\mathrm{Cu}, \mathrm{Cd}, \mathrm{Cr}, \mathrm{Pb}, .$. may alter the photosynthetic apparatus, decrease photosystem ॥ energetic connectivity $[23,24]$. In the present study, Cu at the concentration of $2 \mathrm{mg} / \mathrm{L}$ or higher caused significant inhibition on the growth of the microalgae Pediastrum sp. The results are in line with the previous observation that the low initial bioaccumulation of Cu by microgreen algae was found to be responsible for its tolerance to Cu [18]. However, the tested species exhibited a tolerance response to Cu with 96h-EC50 higher than other species such as Dunaliella sp., Minutocellus sp. and Nannochloropsis sp. [25].

\subsection{Lipid accumulation}

Total lipid content of Pediastrum sp. exposure to different Cu concentrations was showed in Figure 3. Results indicated that different concentration of $\mathrm{Cu}$ caused different effects on lipid accumulation. Cu at concentration of 0.1 and $0.5 \mathrm{mg} / \mathrm{L}$ led to a significant increase in total lipid production. However, $\mathrm{Cu}$ at the concentration of $2 \mathrm{mg} / \mathrm{L}$ did not influence lipid production. Further increasing of $\mathrm{Cu}$ (5 and $15 \mathrm{mg} / \mathrm{L}$ ) caused decreased greatly in total lipid production in Pediastrum sp. (Figure 3). The total lipid level in Pediastrum sp. is little lower than the previous reports in other green algae such as the Scenedesmus sp. [26] and the Monoraphidium sp. [27].

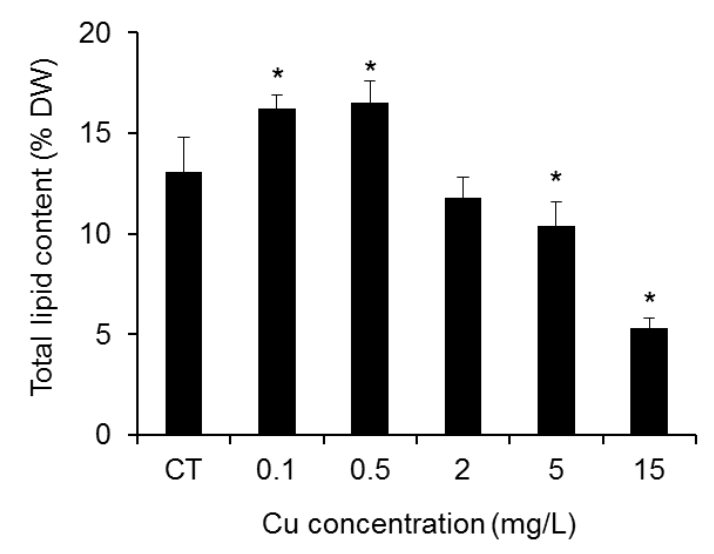

Figure 3. Total lipid content of Pediastrum sp. under different concentrations of $\mathrm{Cu}$.

Previous studies have indicated that heavy metals like cadmium, copper, and zinc are known to increase the total lipid content in the flagellate eukaryotes Euglena gracilis or in green alga Chlorella sp. [28]. Total lipid content of green algae C. minutissima significantly increased by $21 \%$ and $94 \%$, respectively with the addition of low concentration of cadmium and copper [28], but an excessively high concentration of $\mathrm{Pb}^{2+}$ in the culture medium had an inhibitory effect on the growth and lipid production of Scenedesmus sp. Liu et al. (2008) [29] also reported the effect of iron on C. vulgaris and the total lipid content was raised up to $56.6 \%$. The present study results are in line with previous observations that low concentrations of $\mathrm{Cu}$ were beneficial for biomass production and lipid accumulation but higher Cu concentration resulted in toxic to green algae [27].

\subsection{Copper removal and bioaccumulation}

The removal capacity and accumulation of $\mathrm{Cu}$ by Pediastrum sp. were showed in Figure 4. When Cu concentration was lower than $2 \mathrm{mg} / \mathrm{L}$, more than $80 \%$ of $\mathrm{Cu}$ was removed. However, a significant decrease of Cu removal capacity was observed when exposed Pediastrum sp. to $\mathrm{Cu}$ at 5 and $15 \mathrm{mg} / \mathrm{L}$ (Figure 4a). Probably, the inhibition on the growth of Pediastrum sp. has resulted in a significant reduction of Cu removal capacity in these treatments. The level of Cu accumulated in the living cell of Pediastrum sp. was shown in Figure 4b. Higher initial metal concentration resulted in greater $\mathrm{Cu}$ accumulation. The lowest Cu concentration (0.07 mg/g DW) was observed in the treatment with $0.1 \mathrm{mg} / \mathrm{L}$ and the highest $\mathrm{Cu}$ concentration (5.2 $\mathrm{mg} / \mathrm{g}$ DW) was recorded in the treatment with $15 \mathrm{mg} / \mathrm{L}$ (Figure 4b).
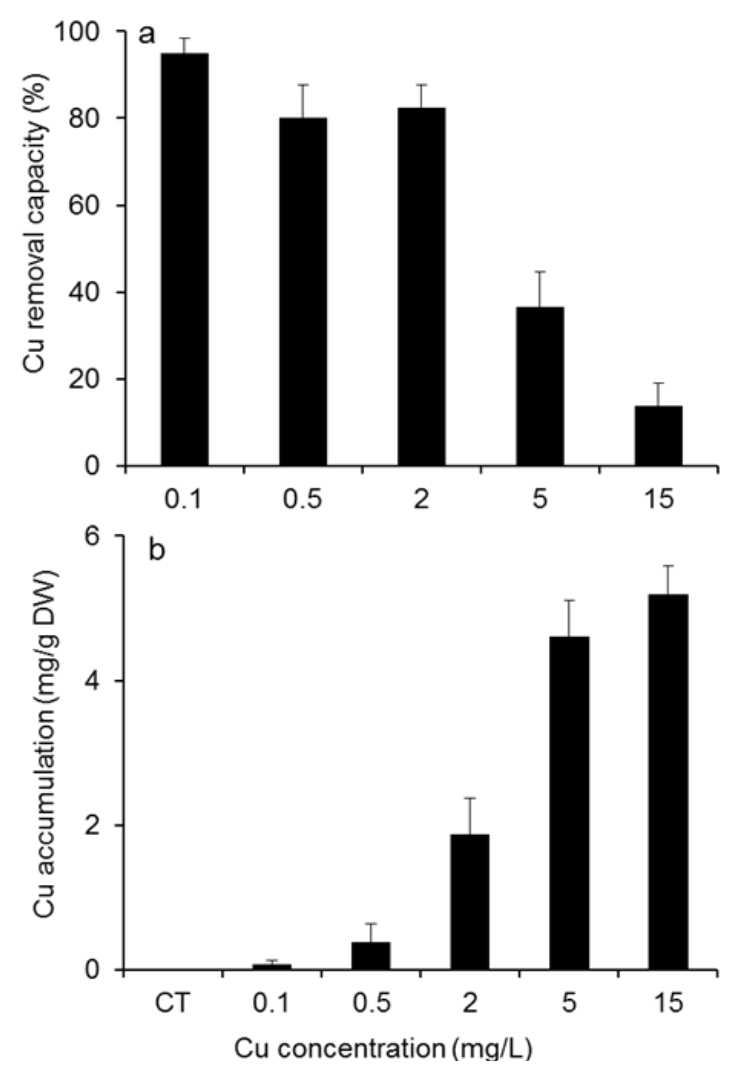

Figure 4. Cu removal capacity (a) and accumulation by Pediastrum sp. (b). 
Previous studies have indicated that microgreen algae are potential in the removal of heavy metal from aqueous solution [18, 25]. Microgreen algae such as Scenedesmus and Chlorella are often used as a promising tool for heavy metal remediation [7]. The ability to remove heavy metal up to $90 \%$ from aqueous solution has been observed in Scenedesmus sp. and Chlorella sp. [7]. However, the removal rate of the metal ion in microalgae may depend on several variables such as initial concentration, exposure duration, and target species. Yan and Pan (2002) [18] demonstrated that the bioaccumulation of Cu by the microgreen algae Closterium lunula was directly proportional to the initial Cu concentration. In general, higher initial Cu concentration results in greater uptake ratio [7]. Microalgae uptake metal via the two main mechanisms: adsorption on to the cell surface, and (a slower) active uptake into the cytoplasm. However, Flouty and Estephane (2012) [30] found that synergistic and antagonistic effects between $\mathrm{Cu}$ and $\mathrm{Pb}$ were observed in binary metal systems which imply that the bioaccumulation process is much more dynamic. The present study indicated that the microgreen algae Pediastrum sp. has ability to uptake and remove Cu from aqueous solution at a concentration up to $2 \mathrm{mg} / \mathrm{L}$. Higher cu concentration caused an adverse effect on the cell growth and consequently decreasing the removal capacity. Further investigation is needed to better understand the uptake mechanism of Cu in microalgae.

\section{Conclusions}

This study indicated that living biomass of Pediastrum sp. exhibited the ability to biosorb and bioaccumulate $\mathrm{Cu}$, and has the potential for lipid production. Both initial Cu concentration and algae biomass had influential effects on Cu uptake and removal as well as total lipid accumulation. At a suitable concentration of Cu in water may exhibit high removal efficiency and enhanced total lipid content in the Pediastrum sp. However, $\mathrm{Cu}$ at high concentration could cause toxic to the green algae and consequently decreasing the removal rate as well as reducing total lipid production. The present results demonstrated that microalgae such as Pediastrum sp. is a promising tool for heavy metal remediation as well as a biomaterial for biofuel production.

\section{Acknowledgments}

This research was founded by Vietnam Academy of Science and Technology (VAST), under grant number "VAST-KHCBKHSS".

\section{References}

[1] Hamed, S.M., Selim, S., Klöck, G. \& AbdElgawad, H. (2017). Sensitivity of two green microalgae to copper stress: Growth, oxidative and antioxidants analyses. Ecotoxicology and Environmental Safety 144: 19-25.

[2] Sabatini, S.E., Juáre,z Á.B., Eppis, M.R., Bianchi, L.,
Luquet, C.M. \& Ríos de Molina, M.d.C. (2009). Oxidative stress and antioxidant defenses in two green microalgae exposed to copper. Ecotoxicology and Environmental Safety 72(4): 1200-1206.

[3] Kalinowska, R. \& Pawlik-Skowrońska, B. (2010). Response of two terrestrial green microalgae (Chlorophyta, Trebouxiophyceae) isolated from Curich and unpolluted soils to copper stress. Environmental Pollution 158(8): 2778-2785.

[4] Sáez, C.A., Roncarati, F., Moenne, A., Moody, A.J. \& Brown, M.T. (2015). Copper-induced intra-specific oxidative damage and antioxidant responses in strains of the brown alga Ectocarpus siliculosus with different pollution histories. Aquatic Toxicology 159: 81-89.

[5] Machado, M. D. \& Soares, E. V. (2016). Short- and Long-Term Exposure to Heavy Metals Induced Oxidative Stress Response in Pseudokirchneriella subcapitata. Clean Soil Air Water 44: 1578-1583.

[6] Zeraatkar, A.K., Ahmadzadeh, H., Talebi, A.F., Moheimani, N.R. \&McHenry, M.P. (2016). Potential use of algae for heavy metal bioremediation, a critical review. Journal of Environmental Management 181: 817-831.

[7] Kumar, S.K., Dahms, H.-U., Won, E.-J., Lee J.-S. \& Shin, K.-H. (2015). Microalgae - A promising tool for heavy metal remediation. Ecotoxicology and Environmental Safety 113: 329-352.

[8] Chen, J., Li J., Dong, W., Zhang, X., Tyagi, R.D., Drogui, P. \& Surampalli, R.Y. (2018). The potential of microalgae in biodiesel production. Renewable and Sustainable Energy Reviews 90: 336-346.

[9] Xin, L., Hong-ying, H. \& Jia, Y. (2010). Lipid accumulation and nutrient removal properties of a newly isolated freshwater microalga, Scenedesmus sp. LX1, growing in secondary effluent. New Biotechnology 27(1): 59-63.

[10] Peña-Castro, J.M., Martínez-Jerónimo, F., EsparzaGarćla, F. \& Cañizares-Villanueva, R.O. (2004). Heavy metals removal by the microalga Scenedesmus incrassatulus in continuous cultures. Bioresource Technology 94(2): 219-222.

[11] Deng, L., Su, Y., Su, H., Wang, X. \& Zhu, X. (2006). Biosorption of copper (II) and lead (II) from aqueous solutions by nonliving green algae Cladophora fascicularis: Equilibrium, kinetics and environmental effects. Adsorption 12(4): 267-277.

[12] Rugnini, L., Costa, G., Congestri, R. \& Bruno, L. (2017). Testing of two different strains of green microalgae for Cu and Ni removal from aqueous media. Science of The Total Environment 601-602: 959-967.

[13] Ouyang, H., Kong, X., He, W., Qin, N., He, Q., Wang, Y., Wang, R. \& Xu, F. (2012). Effects of five heavy metals at sub-lethal concentrations on the growth and 
photosynthesis of Chlorella vulgaris. Chinese Science Bulletin 57(25): 3363-3370.

[14] Bligh, E.G. \& Dyer, W.J. (1959). A rapid method of total lipid extraction and purification. Canadian Journal of Biochemistry and Physiology 37: 911-917.

[15] Fargašová, A., Ondrejkovičová, I. \& Mašlejová, A. (2005). Effects of various copper forms on the freshwater alga, Scenedesmus quadricauda (Turp.) Bréb. Strain Greifswald 15. Bulletin of Environmental Contamination and Toxicology 75(6): 1200-1207.

[16] Lombardi, A.T., Thais, M.D.H., Armando, A.H.V. \& Antonio, L.S. (2007). Toxicity of ionic Copper to the freshwater microalga Scenedesmus acuminatus (Chlorophyceae, Chlorococcales). Phycologia 46(1): 74-78.

[17] Mykhaylenko, N.F. \& Zolotareva, E.K. (2017). The effect of copper and selenium nanocarboxylates on biomass accumulation and photosynthetic energy transduction efficiency of the green algae Chlorella vulgaris. Nanoscale research letters, 12(1), 147.

[18] Yan, H. \& Pan, G. (2002). Toxicity and bioaccumulation of copper in three green microalgal species. Chemosphere 49(5): 471-476.

[19] Levy, J.L., Stauber, J.L. \& Jolley, D.F. (2007). Sensitivity of marine microalgae to copper: The effect of biotic factors on copper adsorption and toxicity. Science of The Total Environment 387(1): 141-154.

[20] Shehata, S.A. \& Badr, S.A. (1980). Growth response of Scenedesmus to different concentrations of copper, cadmium, nickel, zinc, and lead. Environment International 4(5): 431-434.

[21] Jamers, A., Blust, R., De Coen, W., Griffin, J.L. \& Jones, O.A.H. (2013). Copper toxicity in the microalga Chlamydomonas reinhardtii: an integrated approach. BioMetals 26(5): 731-740.

[22] Schamphelaere, D.K.A.C., Nys, C. \& Janssen, C.R.
(2014). Toxicity of lead (Pb) to freshwater green algae: Development and validation of a bioavailability model and inter-species sensitivity comparison. Aquatic Toxicology 155: 348-359.

[23] Källqvist, T. \& Meadows, B.S. (1978). The toxic effect of copper on algae and rotifers from a Soda Lake (Lake Nakuru, East Africa). Water Research 12(10): 771-775.

[24] Dao, L.H.T. \& Beardall, J. (2016). Effects of lead on two green microalgae Chlorella and Scenedesmus: photosystem II activity and heterogeneity. Algal Research 16: 150-159.

[25] Debelius, B., Forja, J.M., DelValls, Á. \& Lubián, L.M. (2009). Toxicity and bioaccumulation of copper and lead in five marine microalgae. Ecotoxicology and Environmental Safety 72(5): 1503-1513.

[26] Ren, H.-Y., Liu, B.-F., Kong, F., Zhao, L., Xie, G.-J. \& Ren, N.-Q. (2014). Enhanced lipid accumulation of green microalga Scenedesmus sp. by metal ions and EDTA addition. Bioresource Technology 169: 763-767.

[27] Che, R., Huang, L. \& Yu, X. (2015). Enhanced biomass production, lipid yield and sedimentation efficiency by iron ion. Bioresource Technology 192: 795-798.

[28] Yang, J., Cao, J., Xing, G. \& Yuan, H. (2015). Lipid production combined with biosorption and bioaccumulation of cadmium, copper, manganese and zinc by oleaginous microalgae Chlorella minutissima UTEX2341. Bioresource Technoly 175: 537-544.

[29] Liu, Z.-Y., Wang, G.-C. \& Zhou, B.-C. (2008). Effect of iron on growth and lipid accumulation in Chlorella vulgaris. Bioresource Technology 99(11): 4717-4722.

[30] Flouty, R. \& Estephane, G. (2012). Bioaccumulation and biosorption of copper and lead by a unicellular algae Chlamydomonas reinhardtii in single and binary metal systems: A comparative study. Journal of Environmental Management 111: 106-114. 